\title{
PARTISIPASI POLITIK PEREMPUAN ISLAM INDONESIA DALAM TRADISI "NU"
}

\author{
Erni Isnaeniyah \\ Jurusan Perbandingan Agama Fakultas Ushuluddin UIN Sunan Gunung Djati Bandung \\ Jl. A.H. Nasution 105 Cibiru, Bandung 40614, Indonesia. \\ E-mail: erniisna@gmail.com
}

\begin{abstract}
This journal explores the role of women when incorporated in Indonesian Islamic women's organization called NU's. This organization contributes a lot to the development of women in Indonesia, particularly concerning social welfare society internally as well as externally. Such as overcoming problems of underage marriage is a national issue that must be resolved. Through the participation of leaders of the Moslem according to its level in the Advisory Board of Marriage and Divorce Settlement. The implications are shown which gives the changes in the educational aspects that depict women in Indonesia in order to compete, health, religious, also active in government agencies such as participating formulate laws as the aspirations of the people's voice (DPR) also at the same time women's organizations this was also able to open communist group in Indonesia.
\end{abstract}

Keywor ds:

NU's Moeslimat, Kowani, political participation

\begin{abstract}
Abstrak
Jurnal ini menelusuri tentang peran perempuan saat tergabung dalam organisasi perempuan islam Indonesia yang dinamakan Muslimat NU. Organisasi ini banyak memberikan kontribusi terhadap perkembangan para para perempuan di Indonesia khususnya yang menyangkut kesejahteraan sosial masyarakat secara internal dan juga eksternal. Seperti mengatasi Masalah perkawinan di bawah umur adalah masalah nasional yang harus segera dituntaskan. Melalui keikutsertaan pimpinan-pimpinan Muslimat menurut tingkatannya dalam Badan Penasihat Perkawinan dan Penyelesaian Perceraian. Implikasi yang ditunjukan yaitu memberi perubahan pada aspek pendidikan yang menggambarkan perempuan di Indonesia agar mampu bersaing, keshatan, keagamaan, juga aktip di lembaga-lembaga pemerintahan seperti ikut merumuskan undang-undang sebagai aspirasi dari suara rakyat (DPR) juga pada saat yang sama organisasi perempuan ini juga mampu membuka kelompok komunis di Indonesia.
\end{abstract}

Kata Kunci:

Muslimat NU, Kowani, Partisipasi Politik.

\section{A. PENDAhULUAN}

Permulaan zaman kaum perempuan bergerak di Indonesia dibuka oleh pikiran Kartini sampai terbangunnya organisasi-organisasi perempuan sejak tahun 1912. ${ }^{1}$ Kartini disebut sebagai pembuka zaman pergerakan, (dikarenakan kepiawaiannya berkomunikasi secara "intelek" dengan para pejabat kaum Hindia Belanda) kemudian disusul dengan berdirinya Boedi Oetomo dan organisasi-organisasi lain, termasuk organisasi perempuan. Poeteri Mardhika, atas prakarsa Boedi Utomo, merupakan organisasi perempuan pertama

\footnotetext{
1. Lihat Takashi Shiraishi, An Age In Motion : Populer Radicalism in Java, 1912 - 1926, Cornell University Press, Ithaca 1990.
}

yang berdiri di Indonesia pada tahun 1912. Perkumpulan yang diketuai oleh Theresia Sabaroedin ini beranggotakan 132 orang.

Transformasi kesadaran akan pentingnya sebuah pergerakan tersebut menandakan suatu kesadaran politik baru sebagai bangsa Hindia yang terjajah, dan selanjutnya berjuang untuk mengenyahkan penjajah. Kesadaran tersebut memicu kaum perempuan Islam untuk turut berpartisipasi aktif berjuang bersama kaum laki-laki Islam. Pada umumnya kesadaran itu lahir dari kalangan kaum perempuan Islam yang sudah menjadi anggota gerakan organisasi pembaharuan, namun menginginkan untuk membangun wadah sendiri, dimana wadah tersebut hanya dihuni oleh 
kaumnya supaya lebih leluasa dalam mengaktualisasikan peranannya. Inisiatif seperti itu mendapat respon yang baik dari para pendiri organisasi pergerakan dan pembaharuan.

Dimulai dengan hadirnya Aisyiyah yang lahir pada tahun 1917, adalah organisasi perempuan Islam pertama yang merupakan badan otonom dari organisasi pembaharuan Muhammadiyah. Muslimat Nahdlatul Ulama (selanjutnya disebut Muslimat) adalah badan otonom Nahdlatul Ulama yang lahir dari berbagai irama yang bergolak di kalangan perempuan Islam Indonesia, khususnya perempuan di lingkungan Ahlusunah wal Jamaah. Meskipun disaat kelahirannya Muslimat tidak langsung menjadi sebuah organisasi perempuan Islam yang otonom, namun disesuaikan dengan perkembangan yang terjadi di dalam organisasi induknya NU. Setelah melalui berbagai perjuangan, termasuk perjuangan berat di dalam intern organisasi Nahdlatul Ulama (NU), akhirnya pada muktamar NU ke-15 di Surabaya, tanggal 5-9 Desember 1940, diputuskan pengesahan Muslimat lengkap dengan Anggaran Dasar dan Pengurus Besarnya. Namun demikian, baru dalam Muktamar NU ke-16 di Purwokerto, tepatnya tanggal 29 Maret 1946 Muslimat disahkan dan diresmikan sebagai bagian dari NU. Pada saat itu namanya Nahdlatul Ulama Muslimat disingkat NUM. ${ }^{2}$

Partisipasi perempuan Islam Indonesia yang bergiat dalam organisasi otonom tersebut tidak dapat dipungkiri senantiasa mengalami pasang surut dalam aktivitas perjuangannya, termasuk di dalamnya organisasi Perempuan Islam Muslimat. Kegiatan aktivis organisasi perempuan Islam pada awalnya menekankan pendidikan yang membuka cakrawala kaum perempuan, misalnya memasak, merawat anak, menjahit, dan lain-lain, lebih jauh dari itu memberikan pula kesadaran, yang belakangan dikenal dengan sebutan sebagai

\footnotetext{
2. Penelitian Aisyah Hamid Baidlowi, pada saat penelitian beliau adalah Ketua II Muslimat NU. Penelitian ini berjudul : Profil Organisasi Wanita Islam ; Studi Kasus Muslimat NU, dalam Wanita Islam Indonesia Dalam Kajian Tekstual dan Kontekstual, Jakarta, INIS, 1993, hlm. 84.
}

"emansipasi perempuan," bahwa kaum perempuan memiliki derajat yang sama dengan kaum laki-laki.

Kualitas kesadaran kaum perempuan semakin mengkristal dalam kesadaran politik yang dinyatakan dalam kongres Perempuan I di Yogyakarta. Kongres yang diselenggarakan pada 22 Desember 1928 ini, dua bulan setelah Kongres Pemuda, berpendapat bahwa persamaan derajat akan dicapai dalam susunan masyarakat yang tidak terjajah. Sejak itu kaum perempuan Indonesia melangkah memasuki periode demi periode. Bahkan dalam bentuk gerakan perempuan, mereka turut berjuang dengan berbagai cara. Setelah proklamasi kemerdekaan diumumkan, kaum perempuan Indonesia termasuk kaum perempuan Islam Indonesia dengan organisasi masing-masing bahu-membahu bersama pejuang lain mempertahankan kemerdekaan. ${ }^{3}$

Tetapi kemerdekaan politik untuk kehidupan berbangsa dan bernegara belum sepenuhnya mencerminkan kemerdekaan berpolitik untuk semua golongan, terlihat dari partisipasi yang dijalankan oleh organisasi perempuan Islam Indonesia, khususnya organisasi Perempuan Islam Muslimat. Muslimat selalu dikatakan sebagai wadah perjuangan dan pengabdian perempuan Islam Ahlusunah wal Jamaah, Muslimat juga diharuskan untuk melaksanakan tujuan NU. Meskipun tujuan itu sangat mulia namun terlihat jelas bahwa "Muslimat" belum memiliki keleluasaan dan kemandiriannya sebagai organisasi perempuan Islam otonom untuk membuat program-programnya sendiri. Sebagaimana NU yang sarat dengan tradisitradisi ajaran keagamaannya, tentunya warna Muslimat-pun tidak jauh berbeda dengan organisasi induknya.

Menariknya, sebagaimana NU, kehadiran Muslimat sebagai badan otonom NU dengan seluruh keberadaan programnya sangat tergantung kepada fatwa para Ulama sepuh yang berpengaruh atau disebut dengan "Dewan Syuriah" dan tentunyan seorang Rois

\footnotetext{
3. Lihat Ruth Indiah Rahayu, Politik Gender Orde Baru, Tinjauan Organisasi Perempuan Sejak 1980-an, dalam Prisma No. 5 Edisi Mei 1996 hal 29 - 30.
} 
Aam (pemegang kewenangan keagamaan dan moral tetinggi dalam NU). Meskipun keputusan tersebut berhubungan dengan masalah yang dihadapi oleh kaum perempuan.

Selain itu Muslimat memiliki ciri khas yang dengan mudah dapat membedakan-nya dari organisasi perempuan Islam lainnya yang ada di Indonesia. Perbedaan itu terletak pada identitas intelektual Muslimat, yang setidaknya ditentukan oleh tiga serangkai pemahaman ajaran, yang terdiri dari fiqh menurut mazhab Syafe'i, aqidah menurut mazhab Asy'ari, dan amalan-amalan Sufi dari karyakarya al-Ghazali. Ajaran dan pemahaman intelektual inilah yang membuat Muslimat memiliki keterkaitan yang sangat kuat dengan NU. Sehingga dengan ciri khas inilah dapat dikatakan Muslimat adalah organisasi perempuan Islam Indonesia yang beridentitas kemazhaban. $^{4}$

Disebabkan dengan berciri khas seperti itulah, Muslimat memiliki komitmen yang tertanam secara kokoh dalam jiwa para kader Muslimat sejak berdirinya yang merupakan moto organisasi tersebut yaitu; "Barang siapa yang mengerjakan amal saleh, baik laki-laki maupun perempuan dalam keadaan beriman, maka sesungguhnya akan Aku berikan kepadanya kehidupan yang baik dan sesungguhnya akan Aku beri balasan kepada mereka dengan pahala yang lebih baik dari apa yang mereka telah kerjakan"'(Quran, surah anNahl, ayat 97).

\section{B. HASIL DAN PEMBAHASAN}

\section{Gambaran Umum Organisasi Perempuan Islam Indonesia "Muslimat NU"}

Tidak dapat dipungkiri lagi bahwa Islam adalah salah satu agama besar di dunia saat ini. Penyebaran penganutnya pun tak hanya di Timur Tengah, tetapi berkembang ke Afrika, Eropa, Asia, Australia, dan juga Amerika.

\footnotetext{
4. Martin Van Bruinessen, NU Tradisi Relasi-Relasi, Pencarian Wacana Baru, Yogyakarta, LKIS, 1997 : 20 -22 .
}

Akibat pesatnya kemajuan teknologi dan ilmu pengetahuan pula lah hal ini terjadi. ${ }^{5}$

Dari sejarah kelahirannya, sebagaimana juga NU, Muslimat tidak dapat dipisahkan dari pesantren, karena dari pesantrenlah Muslimat bermula. Karenanya tidak aneh kalau hingga sekarang hubungan Muslimat dengan pesantren sangat erat. Pemimpin Muslimat biasanya adalah istri para pemimpin pesantren. Demikian pula kader-kader Muslimat adalah putriputri kiai atau santri-santri dari pesantren. Kader-kader itu dipersiapkan menjadi pemimpin Muslimat baik melalui persiapan/pengkaderan alamiah maupun terencana/sistematis. Latihan kader Kepemimpinan Muslimat yang pertama diselenggarakan pada tahun 1948 di Madiun, 2 tahun setelah kelahiran Muslimat. Latihan serupa diadakan pada tahun 1953 di Semarang, tahun 1955 di Jakarta, tahun 1962 di Surabaya, tahun 1972, 1978, dan 1989 di Jakarta.

Budaya pesantren yang mengajarkan ketaatan beragama, kemandirian, kerja sama, disiplin, adab yang baik seperti tawadu kepada yang lebih tua, taat kepada pemimpin, menjadi budaya yang "kental" dalam organisasi "Muslimat". Saat Indonesia mendapatkan kemerdekaan sehingga mampu memberikan corak baru pada pergerakan perempuan Indonesia. Organisasi-organisasi perempuan dituntut untuk mengembangkan diri sesuai dengan tuntunan zaman, tidak terkecuali Muslimat. Keikutsertaan anggota-anggota Muslimat dalam kesatuan-kesatuan pejuang maupun PMI (Palang Merah Indonesia), membawa perubahan pola berfikir. Pergaulan dengan anggota dan pimpinan organisasi perempuan lain membawa peningkatan wawasan dan kemampuan mengelola organisasi.

Sejak didirikannya Muslimat berusaha untuk menjalankan organisasinya dengan azas keterbukaan. Pelaksanaan demokrasi tercermin dalam sistem pemilihan langsung dalam menentukan pimpinan yang berlaku dari pusat sampai daerah, dari Kongres sampai Konferensi Wilayah, Cabang dan Anak Cabang.

\footnotetext{
${ }^{5}$ Taufani, "Indonesian Is lam in Religious and Political Struggle Discourse",Al-Albab-Borneo Journal of Religious Studies (BJRS) 4, no. 1 (2015): 101.
} 
Musyawarah menjadi sendi dasar dari pengambilan keputusan. Dalam masalah-masalah agama pimpinan Muslimat selalu berkonsultasi dengan pimpinan Syuriah NU menurut tingkatannya. Dalam masalah-masalah kemasyarakatan Muslimat senantiasa berorientasi kepada kebutuhan masyarakat bawah.

Struktur organisasi Muslimat sama dengan struktur pemerintahan. Pada tingkat pusat kepengurusan Muslimat disebut Pucuk Pimpinan (PP), kemudian berturut-turut ke bawah : Pimpinan Wilayah (Daerah Tingkat I), pimpinan Cabang (Daerah Tingkat II), Pimpinan anak cabang (Tingkat Kecamatan) dan pimpinan Ranting (Tingkat Desa/Kelurahan).

\section{Perjalanan Organisasi Muslimat Nahdlatul Ulama}

Pada perjalanan perjuangannya, Muslimat telah mengalami setidaknya tiga fase perjuangan dari semenjak kelahirannya tahun 1946 sampai berakhirnya masa kolonialisme Belanda, kemudian masa penjajahan Jepang, dan masa kemerdekaan, serta yang terpenting adalah pasca kemerdekaan, dimana masa tersebut Muslimat harus lebih mawas diri serta introspeksi diri, agar mampu meningkatkan kualitas perjuangannya.

Pada Muktamar NU ke-19 di Palembang, NU meningkatkan dirinya menjadi partai politik dan Muslimat yang telah berkembang luas khususnya di pulau Jawa, meningkatkan dirinya menjadi Badan Otonom dari NU dengan nama baru Muslimat Nahdaltul Ulama, disingkat menjadi Muslimat NU.

Muktamar NU ke-20 pada tahun 1954 di Surabaya sesungguhnya adalah kongres Muslimat yang pertama sebagai badan otonom dari NU. Dalam kongres tersebut keputusankeputusan yang diambil adalah pokok-pokok fundamental, baik dalam kerangka nasional maupun menyangkut organisasi.

Untuk menjalankan fungsinya sebagai badan otonom, Muslimat menetapkan peranannya dalam usaha sosial, pendidikan, dakwah dan usaha kemasyarakatan lainnya. Masalah perkawinan di bawah umur adalah masalah nasional yang harus segera dituntaskan. Melalui keikutsertaan pimpinan- pimpinan Muslimat menurut tingkatannya dalam BP4 (Badan Penasihat Perkawinan dan Penyelesaian Perceraian).

Hasil lain adalah adalah bahwa kongres menyadari betapa banyak pengadilan-pengadilan agama yang keputusannya sangat merugikan perempuan, seperti dalam kasus-kasus perceraian, permaduan, serta masalah waris. Setelah Pemilu I tahun 1955, banyak pemimpin Muslimat yang duduk di Pengadilan Agama, tentunya pemimpin Muslimat yang banyak memahami dan menguasai masalah hukum-hukum perkawinan.

Kongres juga menyadari perlunya dan sudah sepantasnya perempuan duduk dalam lembaga-lembaga negara, tentunya disertai dengan argumentasi bahwa Islam telah memberikan ruang gerak yang cukup luas untuk melakanakan emansipasi sesuai dengan kodrat dan martabat perempuan, sayangnya hambatan kultural dalam masalah ini masih sangat kuat. Dalam lingkungan organisasi NU-pun, Muslimat masih harus gigih berjuang mengatasi berbagai masalah, antara lain, penggunaan tabir dalam pertemuan-pertemuan di mana Muslimat diikutsertakan.

Kongres Wanita Indonesia (Kowani) adalah kelanjutan dari Kongres Perempuan Indonesia yang diselenggarakan pada tahun 1928. Kowani merupakan sebuah federasi organisasi-organisasi perempuan tingkat nasional. Sejak tahun 1956 Muslimat telah bergabung dengan Kowani. Kehadiran Muslimat di Kowani ternyata berdampak cukup positif dan menempati posisi yang tidak mengecewakan dan bersama-sama dengan organisasiorganisasi perempuan lainnya untuk memperjuangkan kepentingan perempuan Indonesia, antara lain persamaan hak, masalah buruh/tenaga kerja, masalah upah minimum bagi pekerja perempuan. Peranan Muslimat dalam dekade 1960-an menonjol secara khusus dalam desakan kepada pemerintah untuk membubarkan TK Melati yang dikelola oleh Gerwani /PKI dan mengambil alih Tk tersebut.

Bersama dengan tokoh-tokoh wanita Islam lain, Ketua Umum Muslimat pada waktu itu, Ny. Machmudah Mawardi pada tahun 1967 mendirikan Badan Musyawarah Organisasi 
Islam Wanita Indonesia (BMOIWI) sebagai wadah untuk mempersatukan gerak langkah organisasi-organisasi perempuan Islam dalam hal-hal yang menyangkut kepentingan bersama, khususnya dalam masalah agama. Keanggotaan badan ini adalah organisasi perempuan Islam Indonesia tingkat nasional. Badan yang dipimpin oleh presidium ini bekerja sama dengan Departemen Agama dalam penyuluhan-penyuluhan menyangkut haji, peradilan agama, pendidikan agama. Badan ini juga bekerja sama dengan Departemen Sosial dalam program peningkatan peran perempuan di pedesaan. Dalam Badan Kerjasama Wanita Militer pada periode 1958 s/d 1962 dan selanjutnya dalam Badan Potensi Wanita Karya pada periode 1962 s/d 1964 Muslimat juga terwakili.

Partisipasi Muslimat tidak hanya di lingkungan domestik namun sektor publik-pun mulai dirambah oleh Muslimat, seperti "panggung" Parlemen-pun turut pula diwarnainya, bahkan dirasakan sangat dominan dalam masalah-masalah keperempuanan, contohnya seperti dalam penolakan terhadap Pengajuan Undang-undang perkawinan dari fraksi Golkar yang dipahami Muslimat sangat bertentangan dengan hukum-hukum Islam. Selain itu anggota-anggota DPR dari fraksi Muslimat mempunyai peranan yang cukup potensial dalam menghasilkan berbagai undang-undang, misalnya UU Kesejahteraan Sosial. Dalam kegiatan Internasional-pun Muslimat senantiasa menyertakan perwakilannya, misalnya mengikuti International Council of Women $26^{\text {th }}$ Plenary Conference dan seminar di Bangkok.

Sebagai Badan Otonom dari sebuah partai politik NU (1952-1971), Muslimat berpartisipasi aktif dalam gerakan-gerakan politik, meskipun Muslimat belum pernah menjadi organisasi politik. Dalam forum politik, ketua umum Muslimat I (Ny.H.Chadidjah Dahlan) tahun 1948 duduk dalam keanggotaan KNIP (Komite Nasional Indonesia Pusat). Muslimat juga tetap berkembang seimbang dengan pertumbuhan cabang-cabangnya.

Pada perjalanan selanjutnya, setelah mengalami masa keprihatinan yang panjang, dalam kongres ke-10 tahun 1979 di Semarang, Muslimat bangkit dengan langkah tegap penuh percaya diri dan bersama seluruh kekuatan turut membangun di segala bidang sesuai dengan tuntutan-tuntutan dan tahapan-tahapan yang diperlukan. Selain itu kerja sama dijalin dengan berbagai lembaga/yayasan, organisasi dalam maupun luar negeri, juga dengan berbagai departemen, terutama setelah NU memutuskan kembali kepada Khittah 1926 dan menerima azas tunggal Pancasila.

Setelah mengadakan reorientasi organisasi semenjak terpilihnya tokoh muda yang bernama Abdurrahman Wahid, sebagai ketua umum badan Eksekutif (Tanfidziyah) pada muktamar 1984, yang telah memberi wajah baru bagi organisasi NU. Tokoh ini mewakili gagasan-gagasan baru yang agak berbeda dengan gagasan para pendahulu mengenai apa yang harus diperjuangkan NU. Perubahan iklim di tubuh NU tentu saja membawa konsekuensi baru, dan diharapkan dampak terbaik dapat dirasakan oleh seluruh jajaran kader Muslimat dari pusat sampai daerah. ${ }^{6}$

Memasuki abad baru saat ini, yang dikatakan oleh sebagian tokoh adalah tahun keberuntungan kaum perempuan. Diharapkan khususnya bagi organisasi perempuan Islam Indonesia Muslimat, dapat meningkatkan qualitas-nya sebagai organisasi perempuan Islam Indonesia yang penuh harapan yang akan mengantarkan kaum perempuan Indonesia kepada kemajuan dan keberhasilan. Saat ini, NU dipimpin oleh seorang yang sangat bijak K.H. Hasyim Muzadi yang terpilih dalam Muktamar di Kediri akhir tahun 1999, diharapkan di bawah kepemimpinannya NU dan khususnya Muslimat dapat "dihantarkannya" kepada kesuksessan. ${ }^{7}$

\footnotetext{
6. Ais yah Hamid Baidlowi, Peneliti Muslimat NU, disini beliau berperan bukan sebagai Ketua II Muslimat, tapi lebih kepada seorang perempuan aktivis dan salah seorang Ketua KOWANI.

7. KH. Hasyim Muzadi terpilih sebagai Ketua Tanfidziyah (PB) NU pada Muktamar di Kediri thn 1999.
} 


\section{Telaah Teori-teori dalam Pendekatan Partisipasi Perempuan Islam Indonesia dalam Tradisi NU}

Secara aktual akan dapat memberikan sebuah gambaran dengan menampilkan bagaimana perempuan Islam menjalankan aktivitas dinamisnya selain sebagai status ibu rumah tangga dan isteri yang mendapingi suami. Salah satu aspek dinamis dari status ibu rumah tangga dan isteri adalah berpartisipasi di sektor publik dan berperan sebagai politikus.

Setiap perempuan Islam yang memilih dunia politik sebagai salah satu aktivitas publiknya, pada dasarnya selalu didasari akan adanya suatu tanggung jawab yang bernuansa ibadah dan suatu keharusan yang berdasarkan keyakinan terhadap agamanya (Islam), bahwa tugas mulia ini harus ditanggung secara bersama-sama dengan mitra kerjanya yaitu komunitas laki-laki.

Ada beberapa pendekatan teori yang dapat digunakan dalam kajian ini. Salah satunya adalah teori Struktural-Fungsional yang merupakan salah satu grand teori dalam ilmu sosiologi, ditambah dengan beberapa teori sebagai pelengkap. William F.Ogburn dan Talcott Parson adalah para sosiolog ternama yang mengembangkan pendekatan strukturalfungsional dalam kehidupan keluarga pada abad ke-20. Pendekatan ini mempunyai warna yang jelas, yaitu mengakui adanya segala keberagaman dalam kehidupan sosial. Dan keberagaman ini merupakan sumber utama dari adanya struktur masyarakat. Dan akhirnya keragaman dalam fungsi sesuai dengan posisi seseorang dalam struktur sebuah sistem. ${ }^{8}$

Selain itu pendekatan teori bagi kajian partisipasi politik, khususnya mengenai partisipasi politik perempuan Islam Indonesia, setidaknya dapat disandarkan kepada apa yang disebut dengan skema konseptual dalam Sosiologi Politik berdasarkan kepada teori-

\footnotetext{
8. Ratna Megawangi, seorang Dosen IPB dengan gelar $\mathrm{Ph} . \mathrm{D}$. dalam bidang International Food and Nutrition Policy. sangat tertarik pada kehidupan para Sufi. Akhirnya dia membuat buku dengan judul MEMBIARKAN BERBEDA, sudut pandang baru tentang Relasi Gender, Bandung, Mizan 1999, hlm. 56 57.
}

teori yang dihasilkan oleh setidaknya dua orang tokoh menggagas kajian Sosiologi Politik yaitu; Karl Marx (1818 - 1883) dan Max Weber (1864 - 1920). Secara sederhana Partisipasi politik ialah, keterlibatan individu sampai kepada bermacam-macam tingkatan di dalam sistem politik. Aktivitas politik itu bisa bergerak dari ketidakterlibatan sampai dengan aktivitas jabatannya. ${ }^{9}$

Selain itu kajian perempuan dalam politik biasanya dapat dibedakan menjadi dua sasaran kajian. Pertama, kajian dan penelitian yang memfokuskan pada peranan perempuan dalam berbagai aspek atau fungsi politik, seperti sosialisasi politik, partisipasi politik, dan elite politik. Kedua, kajian mengenai perempuan dan politik sebagai sub bidang kajian dalam ilmu politik dan sosiologi politik, feminisme memiliki substansi kajian (ontologi), metodologi, epistemologi, dan tujuan kajian (axiologi) tersendiri. ${ }^{10}$

Sementara itu, kajian perempuan dalam politik atau penjelasan tentang partisipasi politik perempuan biasanya dilakukan melalui dua sudut pandang. Pertama, penjelasan terhadap pola khusus partisipasi perempuan, yang umumnya bersifat kendala. Kendala partisipasi perempuan bersumber pada, antara lain, perbedaan sosialisasi antara perempuan dan laki-laki, karakteristik biologis dan siklus kehidupan, akses yang tidak sama terhadap sumber daya, profesi dan keuangan, penghargaan yang rendah terhadap pekerjaan yang secara tradisional dilakukan perempuan. Kendala lain karena perempuan memiliki mental minor, mental yang lebih menonjolkan aktivitas di sektor domestik. Kedua, penjelasan terhadap berbagai bidang keterlibatan perempuan dalam politik, seperti partisipasi politik, sosialisasi politik, perilaku politik pada peringkat warga negara biasa, dan perilaku politik perempuan pada peringkat elite politik.

\footnotetext{
9. Dalam Pengantar SOSIOLOGI POLITIK, Michael Rush dan Phillip Althoff diterjemahkan dari An Introduction to Political Sociology, Jakarta, Rajawali Press, $1995: 23$.

10. Muhammad Asfar, Wanita dan Politik antar Karir dan Jabatan Suami, (Hasil penelitian) dalam Prisma No. 5. Edisi Mei 96. Hal 3 - 16.
} 
Perbedaan perilaku politik perempuan dan laki-laki pada peringkat warga negara biasa atau elite politik, dijelaskan melalui perbedaan sejarah sosialisasinya, yaitu bagaimana perempuan belajar mengenai sex roles yang pantas di bidang politik. ${ }^{11}$

Sedangkan Islam memandang perempuan dari sudut pandang keimanan sebagai individu anggota umat yang dikaitkan dengan individu yang lain dengan ikatan aqidah. Yang dimaksud ikatan aqidah ini ialah sebagai ikatan yang membentuk gerakan politik yang berperan sebagai motor penggerak aktivitas umat dengan tujuan mewujudkan syariat yang menjadi hukum umat. Oleh sebab itu kompetensi sebagai salah satu syarat bagi perempuan Islam untuk terjun dan berpartisipasi di dunia politik di bawah naungan realitas pemikiran ini menjadi suatu persoalan yang lazim diperbincangkan sebelum terjun di kancah dunia politik dalam umat. Dalam hal ini kompetensi yang diperoleh ketika perempuan memiliki kesadaran politik yang sangat didambakan oleh Islam agar perempuan Islam dapat bangkit mengemban tanggung jawab politik dan sosialnya. Tanggung jawab yang dilaksanakan dalam konteks sosial yang boleh jadi menjadi halangan atau dorongan bagi praktek tersebut, yakni konteks sosial yang menjadi tempat tinggal kaum Muslim dengan berbagai macam dimensinya agar perempuan Muslim memiliki kemungkinan untuk berpartisipasi dalam gerakan politik umat. $^{12}$

\section{4. ubungan Sekularisasi Dan Sekularisme}

Walaupun muncul cukup banyak tulisan tentang Nahdlatul Ulama (NU), namun belum ada tulisan yang secara tuntas menyoroti organisasi sosial-keagamaan ini melalui beberapa pendekatan yang saling berkait. Umumnya tulisan tersebut hanya menekankan satu atau dua aspek tertentu saja, sehingga seringkali terjebak oleh penonjolan aspek-aspek yang menjadi fokusnya, dan mengecilkan aspek-aspek lain yang sama penting peranannya dalam kehidupan NU sendiri. ${ }^{13}$

Hal ini disebabkan Nahdlatul Ulama (NU) adalah sebuah fenomena, dengan memiliki berbagai gejala unik, membicarakan NU bagaikan menyelami sebuah "oase tanpa batas", bukan hanya di Indonesia tetapi juga di seluruh dunia Muslim. NU, adalah sebuah organisasi ulama tradisionalis yang memiliki pengikut yang besar jumlahnya, organisasi non-pemerintah paling besar yang masih bertahan dan mengakar di kalangan bawah. NU paling tidak, mewakili dua puluh juta Muslim, yang meski tidak selalu terdaftar sebagai anggota resmi namun merasa terikat kepadanya melalui ikatan-ikatan kesetiaan primordial. Sejalan dengan tradisi Islam Sunni, NU dalam lintasan sejarahnya di masa lalu, dipandang memiliki sikap akomodatif terhadap pemerintah, serta para tokoh dan pemimpinnya seringkali dituduh sebagai orang-orang yang sangat oportunis.

Membicarakan keberadaannya (NU) terasa tidak lengkap apabila kita tidak menyentuh sejarah kelahirannya yang dirasakan sangat "paradoks" bagi keadaan pada saat itu. Nahdlatul Ulama didirikan pada tahun 1926 oleh sejumlah tokoh tradisional dan usahawan Jawa Timur. Pembentukannya seringkali dijelaskan sebagai reaksi defensif terhadap berbagai aktifitas kelompok reformis, Muhammadiyah, dan kelompok modernis moderat yang aktif dalam gerakan politik,

\footnotetext{
13. Tulisan Abdurrahman Wahid ini merupakan salah satu tulisan dalam buku Tradisi dan Kebangkitan Islam di Asia Tenggara dengan editor Taufik Abdullah \& Sharon Siddigal yang diterjemahkan dari aslinya Islam dan Society in Southeast Asia, Jakarta, $\mathrm{LP}_{3} \mathrm{ES}, 1989$, hal. 193-206.
} 
Sarekat Islam (SI). Sebagai organisasi modern yang dipimpin oleh para intelektual dan politisi jenis baru dan mengaku mewakili kepentingan seluruh umat Islam Indonesia, SI dan Muhammadiyah merupakan ancaman serius terhadap posisi para pemimpin tradisional umat, Kiai. Dapat dilihat, bahwa aktivitas Muhammadiyah dan Sarekat Islam merupakan faktor yang penting, walaupun kelahiran NU bukanlah semata-mata sebuah reaksi defensif terhadap pengaruh mereka yang semakin kuat.

Meskipun peristiwa berdirinya NU berlangsung di Surabaya dan kebanyakan dari tokoh pendiri berdiam di kota tersebut, bukan berarti orientasi dasar didirikannya organisasi ini berdasarkan kekotaan. Pesantren dan pondok yang merupakan corak Islam yang diwakili NU pada dasarnya merupakan fenomena pedesaan. Selain itu aspek-aspek utama pembahasan segi tradisi-tradisi NU dapat dilihat pada hal-hal sebagai berikut : Pertama, Tradisi keilmuagamaan yang dikembangkannya, kedua, pandangan kemasyarakatan yang dimilikinya, ketiga, cara pengambilan keputusan umum yang digunakannya, dan keempat, proses rekonsiasi internalnya. Kesemua aspek utama itu berkait satu sama lain, bahkan seringkali berfungsi saling tumpang tindih, walaupun secara keseluruhan berpola saling menunjang.

Tradisi keilmuagamaan yang dianut oleh NU, sebagaimana dikemukakan oleh Zamakhsyari Dhofier ${ }^{14}$ dalam salah satu tulisannya dan yang sebenarnya telah dikemukakan secara terbuka oleh segenap warga NU sendiri sejak permulaan berdirinya NU bertumpu pada pengertian tersendiri tentang apa yang oleh NU disebut aqidah ahlussunnah wal jama'ah. Doktrin tersebut berpangkal pada tiga buah panutan inti; Mengikuti paham Al-Asyari dan Al-Maturidi dalam ber-tauhid (mengesakan Allah dan mengakui keutusan Muhammad), mengikuti salah satu mazhab fiqh yang empat (Hanafi, Maliki, Syafi'I dan Hambali) dan mengikuti

14. Zamakhsyari Dhofier menulis tentang NU dengan judul bukunya Tradisi-tradisi keagamaan Pesantren, Jakarta, LP3ES, 1982. cara yang ditetapkan Al-Junaid Al-Baghdadi dalam bertarekat atau bertasawuf. Inti dari tradisi keilmuan yang dianut NU adalah perpautan organisasi antara tauhid, fiqh, dan tasawuf secara tidak berkeputusan, yang dalam jangka panjang menumbuhkan pandangan terpautnya sendiri antara dimensi duniawi dan ukhrawi dari kehidupan. Dalam mengembangkan tradisi keilmuagamaan yang peripurna, NU telah membagi siklus kehidupan para warganya dalam sejumlah lingkaran kegiatan atau bidang perhatian yang baku.

Pemikiran seperti itu, salah satunya bisa dikategorikan sebagai pemikiran hukum yang tertuang dalam kerangka normatif bernama kaidah fiqh (legal maxims, qawa'dul fiqh), menentukan bentuk akhir keputusan hukum yang akan diambil jika kondisi dan persyaratan yang melatar belakangi sesuatu masalah yang tadinya sudah diputuskan telah mengalami perubahan. Di sinilah terletak dinamika pengembangan hukum agama melalui fiqh dapat dilakukan, walaupun dalam batasan-batasan yang tetap masih ketat.

Dari tradisi keilmuagamaan yang dianut oleh warga NU seperti itu sudah tentu logis apabila kemudian muncul pandangan kemasyarakatan yang tidak bercorak "hitamputih". Perpautan kedua dimensi duniawi dan ukhrawi dalam kehidupan manusia tidak memungkinkan penolakan mutlak pada kehidupan dunia maupun kehidupan akhirat. Dengan kata lain, seburuk-buruknya kehidupan dunia, haruslah dijalani dengan kesungguhan dan ketulusan. ${ }^{15}$

Dengan keilmuagamaan yang berlatar belakang fiqh, NU memiliki berbagai pemahaman yang mendalam tentang masalah hukum kemasyarakatan termasuk didalamnya masalah keperempuanan, yang di dalam tubuh organisasi NU perempuan Islam diwakili oleh organisasi otonom-nya NU, yaitu Muslimat.

Masalah partisipasi perempuan Islam dalam sektor publik, termasuk didalamnya partispasi perempuan Islam dalam politik secara garis yang "masih sederhana" NU tidak melarang

\footnotetext{
15. Op.Cit hlm. 197
} 
perempuan Islam untuk turut berpartisipasi. Karena sesungguhnya Islam tidak menghalangi perempuan untuk memasuki berbagai profesi sesuai dengan keahliannya, seperti menjadi guru atau dosen, dokter, pengusaha, menteri, hakim, dan lain-lain, bahkan bila perempuan Islam mampu dan sanggup, dibolehkan menjadi perdana menteri atau kepala negara, asal dalam melaksanakan tugasnya tetap memperhatikan hukum-hukum atau aturan-aturan yang telah ditetapkan oleh Islam, misalnya; tidak terbengkalai urusan dan tugasnya dalam rumah tangga, harus ada izin dan persetujuan dari suaminya bila telah bersuami, juga tidak mendatangkan hal-hal yang negatif terhadap diri dan agamanya.

Hanya saja dalam hal tersebut (pemimpin, hakim), ulama berbeda pendapat dalam menetapkan hukum tentang boleh atau tidaknya kaum perempuan untuk menjadi hakim dan top leader (perdana menteri atau kepala negara). Jumhur ulama berpendapat, bahwa tidak boleh perempuan menjadi hakim atau top leader berdasarkan ayat Al-Quran surat An-Nisa : 34 dan hadits dari Abu Bakrah yang diriwayatkan oleh Bukhari, Ahmad, Nasai dan Tirmizi. ${ }^{16}$

Pada dasarnya membahas masalah partispasi politik perempuan Islam, akan lebih mendasar apabila dijelaskan masalah pembagian peran antara laki-laki dan perempuan dalam Islam dengan memakai perspektif NU. Dalam surat At-Taubah ayat 71. Secara implisit ayat tersebut mengandung pengertian bahwa pembagian peran antara laki-laki dan perempuan sebenarnya tidak ditentukan oleh jenis kelaminnya, tetapi lebih difokuskan pada pelaksanaan fungsi keduanya sebagai khalifah di muka bumi yang harus senantiasa saling tolong menolong untuk mengamalkan ajaran agama di tengah-tengah kehidupan masyarakat.

\footnotetext{
16. Lihat Huzaemah Tahido Yanggo, Kontruksi Fiqh Wanita dalam Peradaban Masyarakat Indonesia Modern, dalam Rekonstruksi Fiqh Perempuan dalam Peradaban Masyarakat Modern. (ed) M. hajar Dewantoro dan Asmawi, diterbitkan oleh PSI UII bekerjasama dengan Penerbit Ababil Yogyakarta, 1996.
}

Sejarah Islam sendiri telah menceritakan bagaimana para istri Rasulullah juga sering terlibat dalam aktivitas publik. Bahkan Rasulullah sendiri tidak pernah melarang isterinya untuk mengikuti kegiatan di luar rumah. Memang harus diakui ada budaya yang memperlemah peran perempuan di wilayah publik yang dianggap menyalahi kodratnya sebagai "orang rumah". Tetapi budaya semacam itu bukanlah bersumber dari Islam. Pada tataran empirik kita dapat menyaksikan bagaimana nilai-nilai budaya Timur Tengah tidak memberi kebebasan yang cukup berarti bagi kaum perempuannya.

Setiap membicarakan masalah partispasi perempuan dalam wilayah publik, khususnya dalam bidang politik akan sampai kepada masalah kepemimpinan (meskipun pada dasarnya partisipasi perempuan Islam dalam politik bukan hanya membicarakan masalah posisi kepemimpinan) menurut Islam yang dikaitkan dengan posisi perempuan, yang pertama dijadikan landasan adalah surat AnNisa' ayat 34. Berdasarkan ayat tersebut, banyak ulama yang menafsirkan sebagai larangan bagi perempuan untuk menduduki semua bentuk posisi kepemimpinan yang melibatkan kaum laki-laki didalamnya.

Selain itu, pencarian legitimasi dari hadits juga dilakukan sebagian ulama dalam rangka memperkuat pendapatnya tentang larangan bagi perempuan yang menjadi pemimpin. Di NU sendiri, para ulama NU yang mengetahui seluk beluk ketatanegaraan pada umumnya cenderung membolehkan perempuan menduduki posisi pemimpin karena dipandang berbeda dengan jabatan al-imam al-'adham. Adapun masalah apakah perempuan mampu serta dapat diterima atau tidak, adalah hal yang bukan pada tempatnya untuk dibahas para ulama. $^{17}$

Wilayah pembahasan mengenai partisipasi perempuan Islam dalam politik, dalam perspektif tradisi NU akan semakin lengkap apabila ditambah dengan membahas dari sisi

17. H.A. Hasyim Muzadi, NAHDLATUL ULAMA di tengah Agenda Persoalan Bangsa, Jakarta, Logos, 1999, hlm. 75-81. 
kitab kuning, penyebabnya adalah kitab kuning merupakan kajian masyarakat pesantren yang notabene adalah massa NU dan dari sanalah NU dihadirkan Dalam lembaran kitab kuning garis besar pandangannya terhadap perempuan memang cukup jelas, bahwa perempuan kedudukannya berada di bawah laki-laki. Akan tetapi hal itu tampaknya tidak berlaku mutlak. Dari sudut tertentu kitab kuning memandang perempuan sejajar dengan laki-laki. Bahkan dari sudut yang lain lagi, memandangnya jauh di atas laki-lak. ${ }^{18}$

Bagi NU dalam tataran ideal (konsep) sesungguhnya tidak melarang perempuan untuk turut aktif berpartisipasi dalam dunia politik, meskipun tentunya tetap ada pembatasanpembatasan khususnya bagi organisasi perempuan Islam Muslimat yang merupakan gambaran perempuan Islam perspektif NU. Pembatasan-pembatasan tersebut meskipun secara eksplisit tidak dijelaskan namun sangat mempengaruhi keberadaan dan kemandirian Muslimat NU.

\section{SIMPULAN}

Pada umumnya organisasi perempuan Islam merupakan bagian dari organisasi massa yang sifatnya nasional, seperti Aisyiyah yang merupakan bagian perempuan dari Muhammadiyah, dan Muslimat bagian dari NU. Sebagai badan otonom dari organisasi induknya, dalam hal ini visi, ideologi, dan kebijakan dan umumnya semua organisasi perempuan Islam mengikuti organisasi induknya. Sebagai badan otonom Muslimat NU didirikan sebagai bidang kewanitaan untuk menunjang perjuangan dan tentunya untuk melaksanakan tujuan NU di kalangan perempuan, yaitu untuk memperjuangkan dan melaksanakan syariat Islam menurut haluan Ahlussunah wal-jamaah. ${ }^{19}$

Eksistensi organisasi-organisasi perempuan Islam khususnya Muslimat NU dalam masya-

\footnotetext{
18. Masdar F. Mas'udi, Perempuan di anatara Lembaran Kitab Kuning, dalam Wanita Islam Indonesia dalam Kajian Tekstual dan Kontekstual, jakarta INIS, 1993, hlm. 155

19. Dikutip dari Syu'bah Asa, Wanita di dalam dan di luar Fiqh, Pesantren thn ke,6 No.2 1989 hlm.14.
}

rakat Indonesia sudah tidak diragukan lagi. Melalui berbagai kegiatan yang telah dilaksanakannya sejak sebelum Indonesia merdeka, Muslimat telah banyak menyumbang bagi perubahan dalam masyarakatnya. Dalam era pembangunan yang telah lebih dari 30 tahun sekarang ini, akselerasi perubahan semakin dipacu dan di bawah pengaruh globalisasi sistem ekonomi, politik, sosial dan budaya, masyarakat semakin didorong memasuki era modernisasi dan industrialisasi. Kondisi ini menuntut organisasi Perempuan Islam khususnya Muslimat NU untuk melakukan peninjauan kritis dan mendasar atas arah, visi, dan programnya agar bisa tetap relevan menjawab tuntutan situasi dan zamannya.

Dalam lingkup kegiatan keorganisasiannya Muslimat senantiasa tidak dapat terpisahkan dari NU, sehingga sangat disayangkan dengan keadaan sebagai badan otonom Muslimat belum mampu mengapresiasikan semua programnya dengan lebih leluasa, padahal dibadingkan dengan organisasi-organisasi perempuan Islam lainnya yang ada di Indonesia Muslimat dilihat lebih mampu menangkap "sinyal-sinyal" kemajuan zaman. Bisa jadi hal ini disebabkan sikap yang kurang tegas dari organisasi induknya, NU. Dengan pemahaman tradisi yang sangat kental dan sosok para tokoh ulama sepuh (yang sering disebut dengan "kiai langitan") yang sangat dominan fatwanya yang salah satunya tentunya berlandasan kepada ajaran kitab kuning yang berisikan hukum-hukum fiqh yang sangat ketat, walaupun dalam tataran ideal fatwa tersebut tidak menghalangi perempuan Islam untuk berpartisipasi lebih bebas dalam wilayah politik, namun kenyataannya dalam tataran empirik tetap memperlihatkan pembatasan-pembatasan yang membuat khususnya bagi Muslimat terlihat "sedikit tidak berdaya" menghadapi fatwa tersebut.

Melihat perkembangan masyarakat Indonesia yang sedang mengalami satu proses perubahan yang sangat cepat menuju masyarakat industri. Kecenderungan utama dari masyarakat industri adalah komoditasi, termasuk mengkomoditian manusia. Dengan bantuan teknologi yang maju sangat pesat, 
kekuatan-kekuatan dominan telah menjadikan mayoritas masyarakat sebagai komoditi yang lemah posisinya dan konsumen yang pasif karena tidak memiliki daya tawar. Mayoritas perempuan, karena posisi dan kapsitasnya yang cenderung lebih tertinggal daripada lakilaki dalam banyak faktor penting, telah menjadi pihak yang paling rentan sebagai komoditi. $^{20}$

Dalam mengantisipasi permasalahan tersebut, langkah penting yang perlu dilakukan adalah penumbuhan kekuatan-kekuatan pengimbang dalam masyarakat yang bisa mengkontrol dan membatasi ekspansi anarkis kekuatan-kekuatan dominan. Perempuan dan organisasi perempuan adalah bagian dari kekuatan pengimbang yang perlu dibangkitkan tersebut dan salah satunya adalah Muslimat NU.

Dalam lingkup kegiatan pengembangan masyarakat lazim dikenal adanya dua pendekatan utama, yaitu fungsional dan struktural. Pendekatan pertama mengasumsikan bahwa satu masyarakat ditata melalui fungsifungsi yang sudah baku dan tidak perlu dipertanyakan lagi. Apa yang perlu dilakukan adalah mengoptimalkan peran fungsi-fungsi tersebut. Dalam kaitannya dengan program pengembangan masyarakat untuk perempuan pendekatan ini bertujuan menjadikan perempuan lebih mampu dan optimal dalam fungsifungsi tradisionalnya. ${ }^{21}$

Pendekatan kedua, sebaliknya, mengasumsikan bahwa masyarakat terdiri atas berbagai kepentingan yang tarik-menarik, dimana pihak yang lebih kuat akhirnya akan memegang kekuasaan dan mendominasi pengambilan keputusan, sementara pihak yang lemah akan kalah dan menjadi marjinal.

Sejauh ini, karena berbagai alasan pendekatan pertama cenderung lebih banyak digunakan oleh berbagai pihak yang menangani isu perempuan, termasuk di dalamnya organisasi-

\footnotetext{
20. Pembahasan dalam bagian ini diambil dari artikel Wardah Hafidz, Gerakan Perempuan dan Trasformasi Bangsa, dalam Kompas edisi 21 April 1992.

21. Diambil dari tulisan Ivan A. Hardar, Persoalan Gender dalam Pengembangan Masyarakat, Pesantren thn ke- 6, No. 2 1989, hlm. 32-40.
}

organisasi perempuan Islam. Program kegiatan organisasi-organisasi perempuan ini pada umumnya lebih cenderung berkisar di bidang pendidikan (TK, kursus keterampilan menjalankan peran sebagai ibu dan isteri); kegiatan karitatif seperti penyantunan anak yatim dan orang jompo; bidang kesehatan (BKIA, membantu pemerintah dalam pelaksanaan program $\mathrm{KB}$ dan peningkatan gizi); dan peningkatan pendapatan untuk menambah penghasilan keluarga.

Kecenderungan ini disebabkan terutama oleh gabungan dari berbagai kecenderungan berikut. Pertama, organisasi-organisasi ini telah terjebak menerima pola pembagian kerja dan sistem hubungan berdasar seksual dimana peran perempuan terutama adalah di sektor domestik, sedangkan laki-laki di sektor publik. Selanjutnya secara teologis, penerimaan ini semakin dikuatkan oleh pemahaman yang konvensional atas ajaran-ajaran agama yang bisa saja dikategorikan lebih memihak kepada kaum laki-laki. Orientasi agama yang konservatif, dalam kasus perempuan memunculkan, di antaranya, fenomena jilbab, musik qasidah, dan sebagainya yang menekankan identitass Islam lebih pada aspek-aspek fisik. Pada akhirnya ekses negatif dari kecenderungan ini adalah terjadinya pendangkalan penghayatan keagamaan yang mengarah kepada ritualisme saja. Artinya, penghayatan keagamaan yang mengartikan ibadah lebih sebagai ketaatan melaksanakan ritual-ritual keagamaan yang akhirnya melepaskan penghayatan kehidupan keagamaan dari relevansinya dengan permasalahan dan kebutuhan nyata masyarakatnya.

Dari pendekatan serta bentuk kegiatan yang dilakukan oleh organisasi-organisasi perempuan Islam dalam program-programnya kurang mengatisipasi ke arah pengembangan masyarakat. Dengan keadaan tersebut organisasi perempuan Islam khususnya Muslimat NU perlu melakukan perubahan mendasar dalam pendekatan pengembangan masyarakatnya. Selanjutnya secara teologis perlu dilakukan reinterpretasi dan kontekstualisasi ajaran Islam terutama yang berkaitan erat 
dengan pembagian peran dan hubungan kerja antara perempuan dan laki-laki.

Dalam permasalahan tersebut, konsep kemandirian menempati kedudukan sangat penting. Kemandirian banyak ditentukan oleh posisi terutama jika kemadirian dipahami sebagai kualitas dalam interaksi relasional, di mana power atau kekuasaan adalah satu aspek penting.

Selanjutnya, melalui program-program pengembangan masyarakat yang dilaksanakannya, organisasi perempuan Islam khususnya Muslimat dapat mengorganisasikan kaum perempuan dalam kegiatan-kegiatan yang mengarahkan untuk menjadi "konsumen yang kritis", dan selanjutnya juga produsen yang

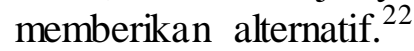

\section{DAFTAR PUSTAKA}

Asa, Syu'bah. Wanita di dalam dan di luar Fiqh, dalam Pesantren thn ke 6 Edisi No. 21989.

Asfar, Muhammad. Wanita dan Politik antara Karir dan Jabatan Suami, (hasil penelitian) dalam Prisma No.5 Edisi Mei 1996.

Bruinessen, Martin Van, NU Tradisi RelasiRelasi, Pencarian Wacana Baru, Yogyakarta: LKiS, 1997.

Dhofier, Zamakhsyari. Tradisi-tradisi Keagamaan Pesantren, Jakarta: LP3ES, 1982.

Hafidz, Wardah. Gerakan Perempuan dan Tranformasi bangsa, Kompas Edisi 21 April 1992.

Hafidz, Wardah. Organisasi wanita Islam dan Arah Pengembangannya, dalam Wanita Islam Indonesia dalam Kajian Tekstual dan Kontekstual, Jakarta, INIS, 1993.

Hamid, Aisyah, Profil Organisasi Wanita Islam; Studi Kasus Muslimat NU, dalam Wanita Islam Indonesia dalam Kajian Tekstual dan Kontekstual, Jakarta, INIS, 1993.

\footnotetext{
22. Diambil dari tulisan Wardah Hafidz, Organisasi Wanita Islam dan Arah Pengembangannya, dalam Wanita Islam Indonesia dalam Tekstual dan Kontekstual, Jakarta, INIS, 1993, hlm. 135-141.
}

Hardar, Ivan A. Persoalan Gender dalam Pengembangan Masyarakat, dalam Pesantren thn ke. 6 edisi No.2 1989.

Izzat, Hibbah Rauf. Wanita dan Politik PANDANGAN ISLAM, Bandung: Remaja Rosda Karya, 1997.

Mas'udi, Masdar F. Perempuan diantara Lembaran Kitab Kuning, dalam Wanita Islam Indonesia dalam Tekstual dan Kontekstual, Jakarta: INIS, 1993.

Megawangi, Ratna. Membiarkan Berbeda, Sudut Pandang Baru Tentang Relasi Gender, Bandung: Mizan, 1999.

Muzadi, Hasyim. Nahdaltul Ulama di Tengah Agenda Persoalan Bangsa, Jakarta, Logos Wacana Ilmu, 1999.

Rush, Michel. dan Althoff, Phillip. Pengantar Sosiologi Politik, Jakarta: Rajawali Press, 1995.

Shiraishi, Takashi. An Age In Motion : Popular Radicalism In Java, 1912-1926, Cornell University Press, Ithaca, 1990.

Surbakti, Ramlan. Feminisme dalam Ilmu Politik, Makalah dalam Seminar Wanita dan Politik, Fisip Universitas Airlangga, Surabaya: 1993.

Wahid, Abdurrahman. NU dan Islam Dewasa ini di Indonesia, dalam Tradisi dan Kebangkitan Islam Di Asia Tenggara, Jakarta, LP3ES, 1989.

Yanggo, Huzaemah Tahido. Kontruksi Fiqh Wanita dalam Masyarakat Indonesia Modern, dalam Rakonstruksi Fiqh Perempuan dalam Peradaban Masyarakat Modern, Yogyakarta, diterbitkan oleh oleh Pusat Studi Islam Universitas Islam Indonesia bekerja sama dengan penerbit Ababil, 1996. 